their particular subjects and who do not hesitate to express these wants loudly, lengthily and sometimes lucidly.

The final paper in the Conference, by Jesse H. Shera (Western Reserve) assesses the future of classification and serves as a connecting link with the Dorking Conference. Shera stresses the idea that a classification is the fundamental evidence of the organization of knowledge, noting the place of inference in assigning a class identity to new data. Although he regards commonly-used classifications as "an address-book for the library stacks," he concludes that they are in no danger of being replaced as such. The evidence of several contributors to this meeting shows that with the dictionary catalog it is quite possible to ignore the shortcomings of whatever classification scheme is used since this is not the crux of the information retrieval system.

The collection of papers ends with an excellent summing-up by Donald E. Strout (IIlinois). Only one or two omissions of any consequence may be noted in the composition of the Conference. Most of the experimentation in classification and in the subject analysis of knowledge for library purposes has taken place in special libraries. It is unfortunate that the Conference did not include a brief survey of these innovations. It would also have been interesting to have something on the Colon Classification, on the many good medical classifications produced in this country, and on the Bliss classification, which has some of the enduring qualities of both Dewey and Library of Congress, as well as schedules for mathematics that might please Bartle.

A general meeting such as this is a worthy undertaking and it is hoped that we shall see more of them in the future. The divergent views of the classifiers represent the varying necessities imposed upon different kinds of libraries by the nature of their collections and their clientele. It is entirely possible that the dream of one or two universal classification schemes suitable for all kinds of subjects in all kinds of libraries is now dead, and that we have entered a period to be dominated by specialized classification systems, each adapted to the subject, environment and purpose for which it is to be used. -Phyllis A. Richmond, University of Rochester Library.

\section{Encyclopedia of the Book}

An Encyclopedia of the Book ... Cleveland and New York, The World Publishing Company (London, George Allen and Unwin, Ltd.), [1960]. By Geoffrey Ashall Glaister. 484 p. $\$ 17.50$.

This volume contains an alphabetical glossary of terms, explanations of practices and equipment, and brief identifications of personages related to "paper-making, printing, bookbinding and publishing, with notes on illuminated manuscripts, bibliophiles, private presses, and printing societies" (titlepage). It leans heavily on the Swedish Grafisk Uppslagbok (1951), from which many of the entries have been translated, with or without amplification by the compiler; such entries are identified by the initials G.U. Certain items have been supplied by Dr. Muriel Lock and Mr. Lewis G. Kitcat, and these, also, are identified by the relevant initials. The compiler, Geoffrey Ashall Glaister, dates his introduction at Dacca, Pakistan, where he is British Council Librarian, and he has put eight years of exacting toil into this exhaustive Encyclopedia.

The work consists of six sections, of which the glossary is far and away the largest and most noteworthy, comprising 451 pages of text and illustration. Following this are five appendixes on, respectively, "Some Type Specimens," a highly selective series (p. 543460); "Latin Place Names as Used in the Imprints of Early Printed Books" (p. 461463); "The Contemporary Private Press" (p. 465-469); "Proof Correction Symbols" (p. 471-475); and "A Short Reading List" (p. 477-484). While these appendixes are moderately useful, the value of the glossary so far overshadows them that their inclusion in the volume comes as something of an anticlimax.

The main glossary, on the other hand, stands by itself in the English language. It fills a void in a manner and to a degree that no predecessor has ever attempted. This fact alone places the work in a preferred category; the further fact that the entires it contains are for the most part carefully, accurately, and amply compiled makes the volume deserving of the highest commendation. One hopes for two developments-first. that the publishers will keep the volume (or 
successive editings of the basic text) in print for many years to come, and second, that the compiler will maintain his interest in the work and make certain that revisions are made to keep pace with changing technology, to incorporate fuller coverage, and to take advantage of further investigations throwing brighter light on past practices and personalities.

The volume, of course, is not without its share of inadvertencies-no first printing of a work of such colossal scope could hope to be. (What, exactly, is meant by the seemingly contradictory phrase "pure weak linseed oil" on p. 86?; surely Adam Ramage was not the builder of the first American-made printing press; William Ged's stereotyped edition of Sallust is dated 1739, not 1744; and so on.) The criticism that the needs of an American user are not adequately met is obvious ("California case" and "Job case" would be useful entries, for example). There is a plethora of nonessential, sometimes downright useless, definitions which are either selfevident or readily to be found in any reasonably good dictionary (oblong, bibliopegy, polished calf). The listing of book clubs leaves much to be desired, especially in regard to American ones (only the Grolier Club is mentioned among the half-dozen extremely important American organizations that come easily to mind).

But there is nothing in the above that can -or is intended to-detract from the work in any substantial degree. This is truly an important addition to the literature of books and book-making, furnishing a reference tool that is unique in our language. It can be improved in later editions, but even if this never comes to pass there is no gainsaying the validity and value of Mr. Glaister's contribution.-Roland Baughman, Columbia University Libraries.

\section{Reading Tastes}

Borrowings from the Bristol Library, 17731874; A Unique Record of Reading Vogues. By Paul Kaufman. Charlottesville, Va., Bibliographical Society of the University of Virginia, 1960. 138p. $\$ 5.00$.

Scattered here and there throughout the length and breadth of New England, and doubtless elsewhere in the United States, are ledgers in which have been recorded borrowings from the libraries to which they once belonged. These ledgers, not a few of which date back to the late eighteenth century, are arranged in one of two ways: In some, a page was assigned to each title held by the library, and upon it was recorded the name of each borrower and the dates of withdrawal and return; in others, the arrangement was by borrower's name with listings, as in a bank ledger, of the titles withdrawn. The reviewer has long argued that these records might have some limited value as indices of reading taste during the years of their use. ${ }^{1}$ Limited their value must be, first because in most instances the character of the borrowing public is not revealed, and second, because there is often no way of determining the character of the collection from which the loans were made: e.g., books on history may have been most heavily borrowed because more books on history were available for loan from the collection. Nonetheless, if used cautiously and interpreted judiciously, these registers do throw a little light on the reading interests of subscription library patrons during the early years of our country.

Mr. Kaufman, of the University of Washington Library, who had previously made a tabulation of the borrowings of Southey and Coleridge from the Bristol Library, ${ }^{2}$ has now turned his attention to all the borrowings from that institution revealed in the five registers which span the years from August 23, 1773 to November 29, 1784.

The Bristol Library Society, a voluntary association of the type familiar to students of library history on this side of the Atlantic, was inaugurated in 1773, with a charter membership of 132 citizens who contributed one guinea annually to maintain the organization. Within a year the Society had acquired 574 titles-not an inauspicious beginning for early libraries of this type. Its subscribers came from the middle and uppermiddle classes of Bristol society, thus its use reflects something of the reading tastes of an informed and thoughtful segment of a community with a long cultural tradition. In other words, it would seem to have been

\footnotetext{
1 See the discussion of this problem in the reviewer's Foundations of the Public Library. Chicago. University

of Chicago Press. 1949, 114-123.
2 Modern Philology, v. 21 (1924) $317-320$.
} 